ОЛІйнИкОВ Г. В.,

кандидат медичних наук, доцент, доцент кафедри публічного права (Національний технічний університет «Дніпровська політехніка»)

\title{
BEPECA O. B.,
} психіатр, психотерапевт, нарколог, завідувач Регіонального центру психотерапії і психопрофілактик (К3 «Міська клінічна лікарня № 6» Дніпровської міської ради)

ЛЕНЬ В. В., кандидат юридичних наук, доцент, професор кафедри публічного права (Національний технічний університет "Дніпровська політехніка»)

УДК 575.82:616-055:340

DOI https://doi.org/10.32842/2078-3736/2020.2-2.8

\section{ПІДСТАВИ ОНТОГЕНЕЗУ ПСИХОСОМАТИЧНИХ ДЕЗОРІЄНТАЦІЙ ТА ПРАВОВІ ВІДНОСИНИ В УКРАЇНІ, ПОВ'ЯЗАНІ $З$ ОСОБАМИ, ЯКІ МАЮТЬ ВИКРИВЛЕНУ ГЕНДЕРНУ ІДЕНТИЧНІСТЬ}

У статті розглянуті окремі статеві проблеми, підстави онтогенезу психосоматичних дезорієнтацій осіб, які мають викривлену сексуальну орієнтацію, питання щодо збалансованого співіснування різних категорій населення в українському суспільстві. Причиною виділення злочинів ненависті як окремої категорії правопорушень $\epsilon$ їхня особлива небезпека, тяжкі наслідки для їхніх жертв у суспільстві. Жертви таких злочинів, із погляду психології, відчувають більше негативних емоцій, ніж жертви звичайних злочинів. Ігнорування мотивів упередженості до певних групових ознак людини під час розслідування та покарання таких злочинів залишає в жертви відчуття безпорадності та незахищеності, страху перед повторними злочинами, оскільки вона розуміє, що іiі ознака, яка спровокувала злочин ненависті, все одно залишається на своєму місці, а упереджене ставлення до людей із такою ознакою не піддається публічному засудженню. Суспільна небезпека злочинів ненависті полягає у внесенні розбрату в суспільство, протиставленні однієї соціальної групи іншим, маргіналізації та віктимізації таких груп. Без наявності постійного моніторінгу й аналізу інформації щодо таких випадків неможливо створити об’єктивну картину їх поширеності в суспільстві та політики попередження і протидії.

Причина цього очевидна: гомофобія (нетерпиме, нетолерантне ставлення до гомосексуальності та гомосексуалістів), яка сторіччями поширювалася різними суспільними інститутами - засобами масової інформації, церквами, освітою тощо. Це привчає як самих гомосеасуалів (які $є$ продуктом суспільства, у якому живуть, як і решта їхніх співгромадян), так і широкий загал дивитися на природні почуття та стосунки ЛГБТ-людей як на щось аморальне, недозволене, погане, засуджуване. У такій ситуації українські ЛГБТ вимушені долати

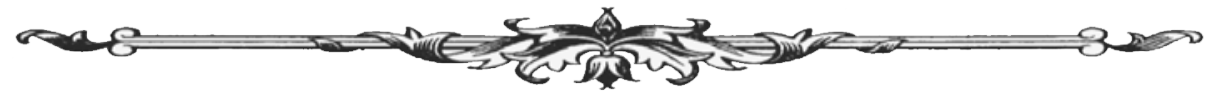


як внутрішні психологічні комплекси, що нав’язує їм традиційна гомофобна суспільна мораль, так і реальні проблеми повсякденного життя, що виникають через відповідне ставлення до них із боку гетеросексуальної більшості. Отже, не дивно, що більшість українських ЛГБТ приховують свою сексуальну орієнтацію, моральні та фізичні особливості, створюючи відповідні структури.

Ключові слова: ЛГБТ, тендерна ідентичність, шлюб, сім'я, одностатеві відносини, психічні розлади, психосоматика, онтогенез, злочин.

Oleinikov H. V., Veresa O. V., Len V. V. Ontogenesis of psychosomatic disorders and legal relations in Ukraine related to persons who have gender-disability

The article discusses individual sexual problems, the foundations of psychosomatic disorientation of people who have a curved sexual orientation, issues of balanced coexistence of various categories of the population in Ukrainian society. The causes of sexual problems, the allocation of hate crimes, as a separate category of offenses pose a special danger with serious consequences for society. Victims of crime, in terms of psychology, recognize more negative emotions than victims of ordinary crimes. Ignoring the motives of prejudice for individual group characteristics of a person in the investigation and punishment of such crimes, leaves the victim a state of helplessness and insecurity, fear of repeated crimes, since she understands her peculiarity, which provoked the crime of hatred, still remains in place, and the prejudiced attitude people with such signs defy public condemnation. The social danger of hate crimes lies in causing discord in society, opposing social groups among themselves, marginalizing and victimizing such groups. Without constant monitoring and analysis of information on such cases, it is impossible to create an objective picture of their presence in society and a policy of prevention and counteraction.

The reason for this is obvious: homophobia (intolerant, intolerant attitude towards homosexuality and homosexuals), which for centuries has been spread by various social institutions, church, education and so on. This teaches both the homosexuals themselves (who are the same product of the society in which their fellow citizens live) and the wider community looking at the natural feelings and attitudes of LGBT people as something immoral, unresolved, bad, condemned. In this situation, Ukrainian LGBT people are forced to overcome both the internal psychological complexes that traditional homophobic public morality imposes on them, and the real problems of everyday life that arise through the corresponding attitude of the heterosexual majority towards them. Therefore, it is not surprising that most Ukrainian LGBT people hide their sexual orientation, moral and physical characteristics, creating appropriate structures.

Key words: $L G B T$, gender identity, marriage, family, one sexual relations, psychonosemas, psychosomatics, ontogenesis, crime.

Проблеми акценту сучасних злочинів, трактування одностатевих відносин, інциденти ненависті в Україні, спричинені упередженим ставленням до осіб із викривленою сексуальною орієнтацією, гендерною ідентичністю, загрожують подальшим загостренням цієї проблеми. Без сумніву, факт нерівності за сексуальною орієнтацією розділяє людей, статева дисфорія, діалог потреб, за гендерними ознаками чоловічої або жіночої статі зумовлюють науковий підхід і обгрунтоване ставлення до даної групи осіб із боку суспільства. Питання браку вірогідної інформації щодо задоволення «базових потреб», складності діагностики патернів ідентичності, презирства, поширення злочинів ненависті за викривленими статевими ознаками, сексуальними переверзіями як нерівними за можливостями залишаються невирішеними. Відсутність ефективних важелів впливу з боку держави, негативне

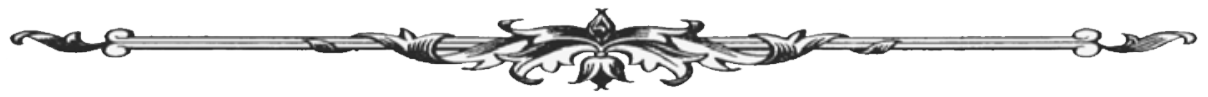


ставлення влади, засудження насильства до груп, найбільш вразливих до ненормальних потягів, їхня маніфістуюча поведінка потребують виправлення ситуації. В Україні мають місце відкриті прояви вербальної і невербальної агресії, непримиримість як окремих осіб, так груп, зокрема із завданням тілесних ушкоджень. Неприродність стосунків, одностатеві шлюби, зокрема із психологічним уявленням самоідентифікації, викривляють у геометричній прогресії маскулінно-фемінні відносини. Осмислення й предмет суперечок, опрацювання концепції людських прав і свобод загалом ініціюють водночас із кардинальним реформуванням застарілих суспільних відносин забезпечення прав, рівності реальної свободи, гуманізації суспільного буття.

Проблемність презирливості, необгрунтованого агресивного ставлення до осіб із викривленими статевими відносинами, видова класифікація, поведінкові відмінності проявляються в разі публічного демонстративного вираження своєї приналежності осіб зі статевими розладами і переверзіями, гендерною психосоматичною орієнтацією. Водночас використання теорії конструктивного сприйняття допоможе концептуально формулювати гіпотези існування осіб із викривленою і неприродною орієнтацією, гендерною ідентичністю та сексуальними девіаціями як носіїв негативної психології.

Злочини, зокрема хуліганство, проти здоров’я особи, інциденти ненависті, надумані прояви антагонізму, складний статус суспільних відносин, історична дійсність, економічне, правове, політичне, культурне становище в державі впливають на дотримання ст. 24 Конституцію щодо механізму реалізації та гарантій соціальних прав і свобод людини в Україні в частині приватності особистого життя. Зазначений вид злочинності в суспільстві не має домінує, проте його рівень, динаміка, географія і структура є показниками сучасного морального здоров'я, духовності, ставлення до основних людських цінностей [1, с. 3-38].

Задекларований нашою країною курс на європейську інтеграцію і погляди, демократизація прав та свобод суспільства, на тлі реформування й удосконалення конституційних гарантій передбачають доповнення, зміну або вікіфікування законів як стратегічну мету для послідовного просування толерантності та неухильну боротьбу зі злочинами й інцидентами ненависті в українському суспільстві згідно з міжнародною практикою. Важливу роль щодо протидії нетерпимості в суспільстві до осіб, які мають викривлену сексуальну орієнтацію, має відіграти громадськість, яка здатна вплинути та змінити громадську думку із цього питання [2, с. 552].

Особливостями злочинності є нетерпимість до різних категорій осіб, зокрема до вищезгаданих осіб, безпідставність втручання в особисте і сімейне життя, агресивні наміри, підбурювання до ворожнечі та мова ненависті, що призводять до вчинення кримінальних злочинів. Статево-рольові стереотипи особистостей, їхні відмінності, класифікація, статева привабливість, виховання, відхилення від природної норми нині суттєво змінилися і не завжди відтворюють реальну дійсність щодо продовження людського роду. Повне розуміння поведінки і мотиваційних станів 3 усіма мотиваціями (мотиваційним блоком), ієрархією і ступенем домінування мотивацій, ідеалів, традицій, без сумніву, потребує розуміння в сучасному суспільстві нашої держави, захисту від втручання або посягань [3, с. 142-260].

Неоднозначність нормальної оцінки щодо нетипових і одностатевих відносин, консерватизм окремих прошарків являють собою загрозу євроінтеграції. Зростання активності та відмінності українського руху ЛГБТ, специфічність міжособистих відносин призвели до підвищеного агресивного тиску з боку ультраправих націоналістичних угруповань. Проблема вирізняється системністю. Висновки щодо винуватості у злочинних діях радикальних угруповань, виявлення обставини порушення прав і свобод потребують публічності з урахуванням об'єктивності правових обвинувачень. Водночас реалізація та гарантування прав людини в Україні є одним із найважливіших чинників, які переконливо свідчать про демократичність державно-правової системи. Зміни анатомічних і психологічних видів спричинили виникнення нових понять, як-от «маскулінність», «фемінінність» і «андрогінність», пов'язаних із гормональним складником, відмінностями і чоловічих і жіночих гормонах $[1$, c. $8-12]$.

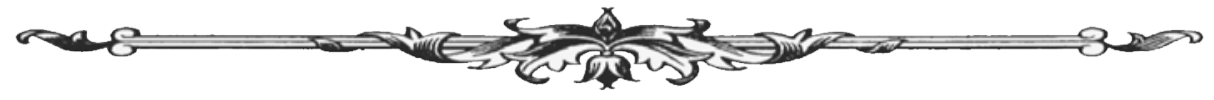


Міжнародне законодавство у сфері злочинів ненависті, досвід закордонних країн, їхня система, стандарти останні півстоліття показують неоднозначне ставлення до питань щодо осіб із нетрадиційною статевою орієнтацією - лесбійок, геїв, бісексуалів і трансгендерів (далі - ЛГБТ), із переверзіями, викривленою і втраченою сексуальною орієнтацією. Їхні різновиди, прайди, психосоматичний феномен, етіологія, ідеї, традиції, почуття, повсякденне життя, формування характеру, душевний стан та взаємодія із широким суспільством ідентифікували специфічність характеристик. Ступінь уявлення реальності, демонстративність поведінки, особливості спілкування, мерила морального права, відкрита дискримінація привели до перегляду відносин і поглиблення нетерпимості за ознаками втрати сексуальної орієнтації, гендерної ідентичності та сексуальної девіації. Об' єктивна реальність, верифікація, особистість складу свідомої мотивації, відчуття, активна діяльність, одяг, напрям поведінки, манерність, відкрите виявлення своїх потреб, почуттів відтворюють реальність статевих викривлень і гендерної ідентичності протилежної статі [4, с. 30-55]. Тобто особливості повсякденного життя, традиції, ідеали, мета, несумісність їх розуміння, пояснюються, по-перше, оцінкою, діями, особистою системою цінностей, специфічністю експресивної поведінки; по-друге, корінням комплексів, з якого почалося формування даної особи. Психофізіологічні можливості сприйняття інформації, потреби, суб'єктивна внутрішня сутність, жага кохання, їх розуміння допомагають у створенні груп із неформальною орієнтацією. Це, у свою чергу, приводе до формування діад, спільнот із сукупністю ідей, ключовими стимулами, неможливістю окремого існування, єдністю мови, потягів, сумісного життя, домінантним комплексом цілеспрямованих сексуально мотивованих дій, іноді з ознаками агресивності. Концепція мотивації, неповторності своєї особистості, зберігання традицій, оцінка специфічних почуттів, настанов, ідей, загальних рис комплексу поведінки формують загали 3 індивідуальними ознаками на тлі глибинних філософських поглядів: функціонального задоволення, переживання і радощі життя [3, с. 244-331]. Моральні й інтелектуальні особливості їхніх угруповань, цілісність характеру, наміри, маніфестації в містах, логіка поведінки, психологічне оточення, стереотипи, ієрархія стійкої життєвої спрямованості, «комфортність відносин» негативно впливають на людей із нормальною сексуальною орієнтацією. За диференціації за правовим аспектом визивають несумісність, конфлікти, загальне невдоволення місцян. Сукупність злочинів визначається проявами вербальної і невербальної агресивної поведінки. Правоохоронцям, визначаючи кримінально-правові риси поведінки агресивних осіб, потрібно дотримуватися верховенства сучасного законодавства [5, с. 30-55].

Зазначених осіб об’єднують глибина потреб, близькість поглядів і мотивація. Задоволення потреб, поведінкова схожість, цілісність, замкнутість, суміжність і загальна зона формування потягів формують тривожність, острахи, напряг, нервозність із проявами фрустрації. Сукупність соціальних стереотипів, їхня особистісна самореалізація, засоби підтримки цілісності таких сімей і угруповань створюють специфічно неприйнятну базу соціального буття [6, с. 67-89]. Етіологічна першооснова особистості дорослої людини, формування їі статі, сексуальна орієнтація, соматичний розвиток, приводячи до амбівалентності, можуть: створювати фантазії, аутопластичні нейрохімічні відхилення, затримання розвитку, формування хвороб із неспроможністю утворення психологічних захисних механізмів [7, с. 125-146].

Аутентична потреба в самоідентифікації, фантазії, нейрохімічні процеси, будуючи соматичний розвиток, формують викривлений статевий стан із проявами асоціальної поведінки в суспільстві. Когнітивний процес, модифікація форм, зміни психосоматики проходять такі етапи розвитку: аутичність, послідовність форм поведінки, із неможливістю подолати ситуаційний стан обставин, несприйняття проблеми як патології з формоутворенням сенсорних емотивно-психічних структур. Динаміка мотивації потреб, як-от фізіологічні, безпеки, кохання, поваги, самоактуалізації, у таких осіб також викривляється, вони розуміються під патологічними кутами. Ідеологічна еволюція, роль задоволення, стан і хвороба 3 первопричин формують складну мотивацію поведінки. Оперуючи соціальними цінностями, стимулюється неспроможність особи контролювати гендерну ідентичність, свій статевий стан, сексуальні відносини і механізми поведінки [8, с. 89-92]. Специфічна незалежність,

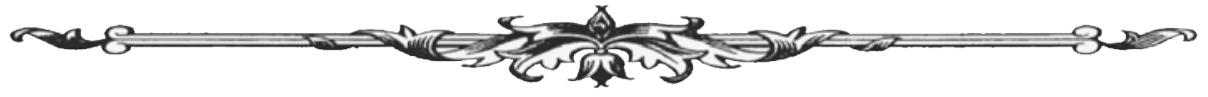


викривлене бачення системи цінностей призводять до змін у когнітивних можливостях. В окремих випадках, стикаючись із життєвими труднощами, міжособистими стосунками, патологічною ідентичністю, виникає викривлення соціальних, духовних і культурних цінностей і поглядів [4, с. 1-2].

Без перебільшення можна зазначити упередженість поведінки широкого загалу до даних груп осіб. Гарантії забезпечення прав осіб на приватність примушують різних фахівців та правоохоронні органи замислюватися та дошукуватися істини у правовому полі. Усвідомлення зв'язку з реаліями життя, існування сімейних, тісних, дружніх емоційних відносин, успіхи науки, прогрес демократії будуть збільшувати рівень ознайомлення українців із життям розвинених країн, що повільно приведе до перегляду реального стану статевих відносин у цій складній сфері. Відповідальне ставлення до проблеми на тлі суспільної думки, соціальних наслідків, фізичного і психічного здоров'я, принципів рівності, однаковості прав усіх громадян України вкрай важливе, потребує сучасного вирішення питань порядку застосування запобіжних заходів до членів ЛГБТ і, можливо, змін Конституції.

Сучасна фундаментальна природа людини XXI ст. як досить ускладненої істоти у процесі становлення являє собою по суті біосоціальну єдність з особливостями анатомічної та психічної організації. Дослідження довели, що складний шлях розвитку сформував сучасну особистість із гендерними особливостями, мотивацією потреб і біологічною ефективністю. Дослідження еволюції, генетика, антропогенез, конституційні, психофізіологічні та структурно-функціональні складники, алгоритм змін, на рівні організації життя, визначили унікальність становища людини. Загальною й унікальною ознакою еволюції людини в період історичного часу є відтворення спадковості правильно і постійно. Еволюція як особливий процес пізнання, пристосування і природного відбору привела до відтворення за ознаками та визначенням сучасного типу людини розумної. Процес сформованості Ното sapiens як гендерної особистості, iï статевої ідентифікації пройшов складний шлях запліднення, ембріогенезу, органогенезу систем і внутрішнього середовища. Важливими ознаками стилю поведінки людини у тваринному світі стали будова частин тіла, прямоходження, анатомічна будова, язик спілкування, гендерні гормональні відмінності, використання орудій побуту. Сучасне уявлення, концепція і унікальність становища людини у природі передусім зумовлені генетичною інформацією, ії змінами, впливом зовнішнього середовища, статевим диморфізмом і відбором із регуляцією й індивідуальними особливостями кожної людини. Морфологічні зміни центральної нервової системи, адаптивна і модифікована внутрішня сутність привели до збільшення об'єму головного мозку, суттєво змінивши стан стабілізації гомеостазу і формування непередбачуваності статевої ідентичності з ознаками онтогенетичної і культурної ритуалізації. Динамізм соціальних процесів, моралі, виховання, суспільний інтерес, науково-технічна революція, еволюція культури, зростання ролі суб'єктивних чинників сформували сутність людської гендерної ідентичності в нових історичних і економічних умовах із формуванням самоідентифікації особи нового типу [9, с. 37-119].

Соціальна організація суспільства, більш складні форми поведінки, статевий відбір досить швидко еволюціонують і визначають неоднозначність у гендерних і сексуальних відносинах як різновиді особистісного конструкта. Особливої актуальності, соціальної важливості нині набули проблеми відхилення сексуальної орієнтації, гендерної ідентичності як у біологічній, так і в соціальній поведінці із проявами захисних стратегій. Специфічність приватного життя, стереотипність поведінки, психологія відносин приводять до формування стійких невеличких скупчень. Подібне світосприйняття, генералізовані мотиви, особливість домінування нетипових сексуальних відносин, наявність негативного лідера, гуморальне підгрунтя, характерна вербальна і невербальна поведінка, поняття «норми», стійка мотивація, наявність невротичних і патопсихологічних розладів виявляють і формують характер «особливості стосунків». Типові ознаки даних осіб: депривація потреб, дефіцит уваги, конфліктні ситуації, опір стереотипам поведінки, пов'язані із загальним непорозуміннями 3 оточуюченням, підкріплені біологічними критеріями i, як наслідок, високим рівнем фрустрації $[4$, с. $30-55]$.

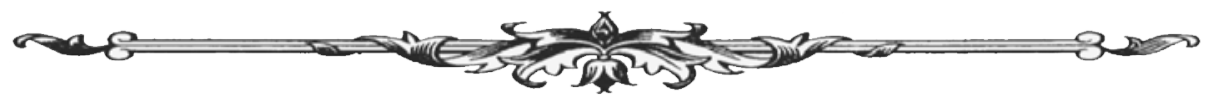


Психічна реальність, чинники задоволення базових потреб, емоційні розлади почуттів, домінуючи, формують комплексуальну залежність, характер, підсилюють і закріплюють складні особистісні ірраціональні стани. Спадковість, зміни експресивної поведінки, соціальне становище, обсяг ідей, традицій, способів мислення створюють спадщину, проти якої будь-які аргументи безсилі. Двоїста природа, уникнення самовизначення, відхилення від різностатевих подружніх і соціальних норм поведінки, виховання, егоцентризм, відчуження, фобії, тривожність формують особистий стиль відносин як конформізм і різні ступені фрустрації. Образ життя, наявність потреб, організація структури мотиваційних систем і поведінки, статевих викривлень, звичок, настанов є основою кореляції та базових задоволень. Міжособистісні відносини формують ієрархії залежно від пріоритетності і головного значення. Пошуки у другій схожості суттєвих ознак формують такі відносини, специфічний емоційний стан, характеризуючи індивідуальність, іiі статус, позицію, роль і ранги, створюючи конкретну соціальну групу або «сім’ю». Дана особа, пристосовуючись, спромагається ідентифікувати себе як особистість, маючи шкідливу природну ідентичність, екстраполюється психологічною залежністю. Завдяки цьому створюються відповідна репутація, авторитет, індивідуалізація контактів, задоволення основних потреб, популярність у групі та колективі подібних осіб. Фрустрація, стрес, труднощі протидії емоційності стану підсилюються фатальністю, проявами самоактуалізації. Головними опонентами рівності сучасних індивідів, подразнювачами, із різною гендерною ідентичністю, внутрішньовидовою агресією є виродження, депривація, дискримінація, деструктивність поведінки, на тлі гомофобії і трансфобії різних прошарків населення в сучасній Україні [6, с. 132-155].

Людина, за своєю анатомічною і фізіологічною сутністю, не завжди відповідає будові і психологічній поведінці. Вивчення проблем статі, гендерної гормональної ідентичності, гормональних відхилень, переверзій, спотворень в орієнтації і психопатій на цьому тлі почалося у XIX ст. Відхилення анатомічного, гормонального і психічного станів формують осіб, яких відносять до лесбіянок, геїв, трансгендерів, бісексуалів, гермафродитів, трансвеститів, транссексуалів і осіб зі специфічними порушеннями психосексуальної індивідуальності та потягів, зокрема переверзіями. Дані стани констатують обгрунтовану об' єктивну реальність [10, с. 227-280]. Усучасних медичних класифікаціях їх відносять до хвороб у МКХ-10, із конкретною рубрикою, диференціацією, ознаками, психологічною поведінкою, створюючи соціальну типологію: F-00 - F-99 « Психічні розлади і розлади поведінки», F-66 «Психологічні і поведінкові розлади, пов'язані зі статевим розвитком і орієнтацією» [11]. Порівняльний аналіз, диференційований підхід дають змогу розділити хвороби і сексуальні переверзії. Тому тільки після медичної діагностики чи проведення психіатричної експертизи особу можна віднести до певної групи 3 гендерною ідентичністю, сексуальною орієнтацією чи переверзією [3, с. 142-376].

Патологічні потяги, сексуальне задоволення нетиповими засобами, їх виникнення, комунікативні риси та розвиток досить складні і не завжди зрозумілі. Без сумніву, порівняльний аналіз виникнення, порушення психосексуального розвитку, їх відхилення, відносини, асоціації, отримання задоволення в подібних осіб визначають формування особистості в кожному випадку по-різному. Порушення сексуальної адаптації в суспільстві, переверзії, їхня специфічність, обрані як неприйнятний факт сексуальної поведінки взагалі, який потребує загальної уваги з боку лікарів, психологів і правоохоронців . Це пов'язано 3 тим, що зазначені психічні розлади, психопатії в суспільстві треба розглядати як розлад потягів за неможливості їх усвідомлено контролювати. Окремо в даній групі стоять особи із психічними розладами, різним ступенем слабоумства, хворобами й ушкодженнями центральної нервової системи. Психічні захворювання, їх загострення, домінанта отримання задоволення, зокрема сексуального, накладають свій специфічний відбиток на статеві орієнтації, вікові відносини, переверзії, спотворення, задоволення нетиповим засобом і домінування 3 різними станами стійкості [3, с. 142-376].

Нейрофізіологічні кореляти психосоматичних розладів формуються i закріплюються у віці від 27 до 40 років. Викривлене бачення і відображення дійсності, реальності

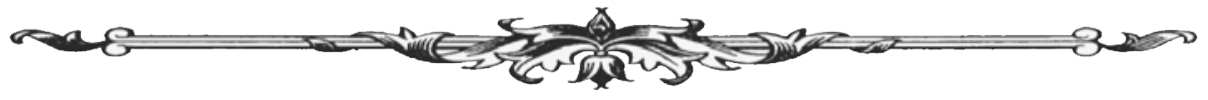


формується і закріплюється центральною, нейровегетативною, ендокринною й імунною системами. Інтереси, кохання, задоволення або опір, захист, агресивність підтримують функціональну єдність такої людини. Дані потреби визначаються конституцією людини, іiі потенційними можливостями, зовнішніми і внутрішніми детермінантами, являють собою внутрішню природу. Сформована свідомість, поведінка, контроль сексуальних потягів домінують у житті даної особистості. Відхилення базового дефіциту потреб від небазових формують невротичний стан із неврозом і психопатологічними відхиленнями. Життєдіяльність, зміни в організмі, виробляючи всякі першочергові імпульси за викривлених сексуальних потягів, створюють когнітивну шкідливість, психічний статус, моделі поведінки. Особи $з$ викривленою сексуальною орієнтацією, переверзіями та гендерною ідентичністю створюють свій реальний внутрішній мир, побудований на спогадах, асоціаціях, еротизмі, ненависті до конкретних осіб, злобі. Загальні правила сприйняття поведінки порушуються. Створений психологічно мотиваційний стан для задоволення своїх базових потреб і спотворені соціальні умовності допомагають, відокремившись, отримати самозадоволення і побудувати свій внутрішній мир. Інтим і сімейні сторони життя, міста перебування осіб із викривленими статевими потягами стають відомими, а оприлюднення інформації може порушити приватність, персональні дані, завдати шкоди інтересам і життю даних осіб. Вибудована свідомо логічна структура постійно активується пошуками серед оточення осіб із викривленими нахилами, із формуванням діад або груп. Вертаючись думками до ідей насолоди, специфічності фрустрації, внутрішніх переживань, депривації, психоемоційного підйому, самовихваляння, активізується в самоідентифікацію. Будучи вимушеними контролювати свою поведінку, дані особи віддають перевагу особам, серед яких можна ввідчувати себе вільно, без емоційних зусиль. Водночас, розуміючи, що дана ідентифікація, символ статусу, не відповідають нормальній людській природі, особи, обстоюючи свої погляди на міжособисті відносини, маючи своє розуміння еротизму і статевої поведінки, набувають нав'язливих потягів із глибинними потребами. Відносна незалежність від фізичного і соціального оточення дозволяють захистити свої недоліки і сформувати стійкість, отримавши самодостатність і симпатії собі подібних. Особливе непорозуміння викликають бісексуалізм і транссексуалізм. Сприйняття катастрофічності стану, особистісна природа, задоволення базових потреб, ущербність, неврози, наявність психопатологічних відхилень, конфлікт і підвищені хворобливі загрози, без альтернативності досягнення мети нормальних відносин у суспільстві, своєї самоідентифікації, викривляються наявністю внутрішніх переживань. Постійно виникаюча потреба, з нав'язливістю отримання задоволення з особами однієї статі, встановленні взаємин із ЛГБТ, нестандартність поведінки, у яких мають місто статеві розлади і сексуальні викривлення, стають нормою життя. Відрізняючись поведінкою й емоційними проявами, дані особи, відчуваючи трагічність свого стану, відчуженість, водночас хочуть знайти порозуміння і кровну близькість з оточенням. Тому, аналізуючи концепцію відповідності природі норми, сприйняття реальності щодо задоволення базових потреб на кшталт «або - або», неможливо розуміти спрощено [7, с. 122-137].

Головними опонентами ЛГБТ, осіб із викривленою сексуальною орієнтацією, гендерною ідентичністю, статевими розладами, сексуальними відхиленнями залишаються українські церкви і праворадикальні націоналістичні організації, які вимагають встановлення кримінальної відповідальності та відображення в сучасному Кримінальному процесуальному кодексі. Можна сформулювати проблему інакше - підсилення проблеми антагонізму, захисту права на приватність, невмотивованість поведінки, констатації презирливості, відкрите і неприховане домінування агресивності загалу до кожного учасника, під час проведення маршів рівності, які практично завжди закінчувалися протиправними діяннями. Узагалі злочинність виявляється деструктивним сприйняттям реальності, цілеспрямованим інтересом, який, формуючи викривлення статевих відносин, гендерної ідентичності, контролює і формує соціальні відносини. Поліція забезпечує охорону, водночас свідомо ігнорує ознаки нетерпимості, диференціацію деструктивної поведінки, побиття і хуліганство осіб із нетрадиційною орієнтацією. Опоненти заходів завжди виступали і декларували

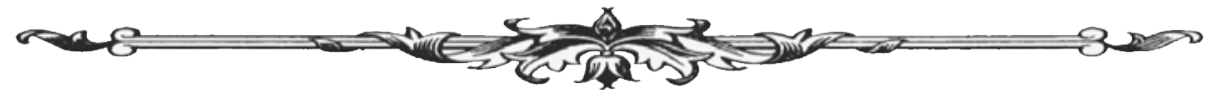


переконання щодо базових потреб, сучасне розуміння концепції культури, викривлення інформації про «нормальність» поведінки, порушення соціальних форм відносин, догматичну сутність і «захист традиційної сім’ї», «дефініцій, які не підходять до повсякденного життя», релігійно-консервативні цінності, поясняючи прояви гомофобії. Загальновизнаним фактом є те, що в сучасній Україні має місто широка компанія звернень до української влади з вимогами істотної переробки понять і соціального захисту традиційних цінностей, приватності можливості розвитку нормальної сім’ї. Уточнення потребують питання щодо запровадження вдосконаленого впливу державної політики, зміни окремих актів законодавства, проти осіб із викривленою сексуальною орієнтацією, гендерною ідентичністю, статевими розладами, сексуальними відхиленнями [1, с. 3-95]. Серед основних напрямів удосконалення юридичної відповідальності щодо конституційних свобод, умов, що сприяли вчиненню злочину, ужиття відповідних запобіжних заходів, наявна проблема нормативно-правового врегулювання законодавства потерпілих із викривленою сексуальною орієнтацією та гендерною ідентичністю як осіб, права яких порушуються: права на приватність особистого життя, вільні статеві відносини, гендерну ідентичність, узагалі відносини із ЛГБТ.

Отже, визнаємо, складна, багатовекторна, ще одна проблема, крім багатьох інших, існує в українському суспільстві.

Навіть більше, вона не вирішується, отже, лише загострюється.

Нам (соціологам, психологам, психотерапевтам, психоаналітикам, генетикам, культурологам, психіатрам, юристам, історикам, політикам тощо) требашукати шляхи її вирішення.

Ця проблема стосується або стосуватиметься тією чи іншою мірою, прямо або опосередковано кожного з нас.

Натепер існують ортодоксальні, непримиренні противники всього, що пов’язано із ЛГБТ; громадяни, які не приймають і не сприймають ЛГБТ; громадяни, які толерантно, терпимо, із розумінням ставляться до представників ЛГБТ, та безпосередньо самі представники ЛГБТ.

Визнаємо, що особливо в часи публічної, громадської активності цих категорій громадян або їхньої більшості обстановка у громадських місцях загострюється. Буває так, що представниками різних сторін вчиняються адміністративні правопорушення або злочини. Здебільшого це: дрібне хуліганство або злочини - умисні легкі, середньої тяжкості або тяжкі тілесні ушкодження (ст. ст. 125, 122, 121 Кримінального кодексу України (далі - КК України)); побої і мордування (ст. 126 КК України); хуліганство (ст. 296 КК України); розбещення неповнолітніх (ст. 156 КК України); втягнення неповнолітніх у злочинну діяльність (ст. 304 КК України); незаконне перешкоджання організації або проведенню зборів, мітингів, походів і демонстрацій (ст. 340 КК України); опір представникові влади, правоохоронного органу, державному виконавцю, приватному виконавцю, члену громадського формування 3 охорони громадського порядку і державного кордону або військовослужбовцеві, уповноваженій особі Фонду гарантування вкладів фізичних осіб (ст. 342 КК України); погроза або насильство щодо працівника правоохоронного органу (ст. 345 КК України); посягання на життя працівника правоохоронного органу, члена громадського формування 3 охорони громадського порядку і державного кордону або військовослужбовця (ст. 348 КК України); погроза або насильство щодо службової особи чи громадянина, який виконує громадський обов’язок (ст. 350 КК України); умисне знищення або пошкодження майна службової особи чи громадянина, який виконує громадський обов’язок (ст. 352 КК України) та ін.

Завдання стоїть не з легких. Усі категорії громадян повинні мирно, толерантно, не заважаючи одне одному, комфортно, демократично співіснувати в одному гармонійно збалансованому суспільстві.

На наш погляд, завдання має такі основні складові аспекти, як: соціальна, громадська, психологічна, правова та політична. Отже, без їх планового, поетапного, відкритого вирішення проблема буде лише поглиблюватися, зростатимуть непорозуміння та розкол в українському суспільстві.

Вихід лише один, не зволікаючи, шукати загальноприйнятне рішення в цій ситуації. Від цього ми нікуди не дінемось. За іншим варіантом, це глухий кут і безвихідь.

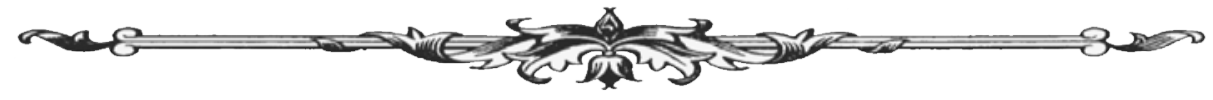




\section{Список використаних джерел:}

1. Кравчук А. Злочини та інциденти ненависті в Україні. Київ : Центр «Наш світ», 2018. C. $3-38$.

2. Нестерович В. Вплив громадськості на прийняття нормативно-правових актів: проблеми конституційної теорії та практики : монографія. Луганськ : РВВ ЛДУВС ім. Е.О. Дідоренка, 2014. 736 с.

3. Еникеева Д. Сексуальная жизнь в норме и патологии : в 2-х кн. Донецк : Сталкер. 1997. 400 с. Кн. 2. С. 142-260.

4. Долаючи перешкоди. Становище ЛГБТ в Україні у 2018 році. Київ : Центр «Наш світ», 2019. С. 30-55.

5. Лоренц К. Агрессия (так называемое «зло»). Человек находит друга. Пер. с нем. и англ. Москва : РИМИС, 2013. С. 32-66.

6. Маслоу А. Мотивация и личность. Пер. с англ. 3-е изд. Санкт-Петербург : Питер. 2019. С. 67-89.

7. Джеймс С. Гротштейн. Расщепление и проективная идентификация Москва : Институт общегуманитарных исследований, 2017. С. 9-18.

8. Столяренко О. Психологія особистості : навчальний посібник. Київ : Центр учбової літератури, 2012. С. 89-92.

9. Елинек Я. Большой иллюстрированный атлас первобытного человека. Пер. Е. Фиштейна / под ред. В. Алексеева. 3-е изд. Прага : Артия, 1985. С. 37-119.

10. Менегетти А. Психосоматика. Пер. с ит. Москва : БФ «Онтопсихология», 2007. C. $227-280$.

11. МКХ-10. V розд.

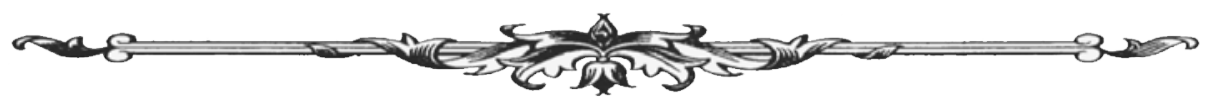

